\title{
Cytochemical characteristics of blood cells from Brazilian tortoises (Testudines: Testudinidae)
}

\author{
G.S. Martins ${ }^{1,2}$, K.C.C. Alevi ${ }^{1,3}$, M.T.V. Azeredo-Oliveira ${ }^{1,3}$ and \\ C.R. Bonini-Domingos ${ }^{1,2}$ \\ ${ }^{1}$ Centro de Estudos de Quelônios, Departamento de Biologia, \\ Instituto de Biociências, Letras e Ciências Exatas, \\ Universidade Estadual Paulista "Júlio de Mesquita Filho", \\ São José do Rio Preto, SP, Brasil \\ 'Laboratório de Hemoglobinas e Genética das Doenças Hematológicas, \\ Departamento de Biologia, Instituto de Biociências, \\ Letras e Ciências Exatas, Universidade Estadual Paulista "Júlio de Mesquita Filho", \\ São José do Rio Preto, SP, Brasil \\ ${ }^{3}$ Laboratório de Biologia Celular, Departamento de Biologia, \\ Instituto de Biociências, Letras e Ciências Exatas, \\ Universidade Estadual Paulista “Júlio de Mesquita Filho", São José do Rio Preto, \\ SP, Brasil
}

Corresponding author: C.R. Bonini-Domingos

E-mail: claudiabonini@sjrp.unesp.br

Genet. Mol. Res. 15 (1): gmr.15017549

Received August 31, 2015

Accepted January 14, 2016

Published March 18, 2016

DOI http://dx.doi.org/10.4238/gmr.15017549

\begin{abstract}
The hematology of wild and captive animals is essential for obtaining details about species and represents a simple method of diagnosing disease and determining prognosis. Few studies have described the morphology of chelonian blood cells, which are more common in sea and freshwater turtle species. Thus, in order to further our understanding and recognition of different chelonian cells types, the present study aimed to describe blood cells from the two species
\end{abstract}


of Brazilian tortoises, Chelonoidis carbonarius and C. denticulatus. Cytochemical analysis of tortoise blood tissue with Panótico ${ }^{\circledR}$, made it possible to describe all the of the chelonian cell types (with the exception of thrombocytes): erythrocytes, agranular leukocytes (monocytes and lymphocytes), and granular leukocytes (eosinophils, heterophils, basophils, and azurophils). These data are of high importance for establishing hematological profiles of Brazilian tortoises and reptiles. Therefore, based on our results and on comparative analyses with data from the literature for other reptile species, we can conclude that the blood cells described for Brazilian tortoises are found in all species of reptiles that have been analyzed thus far, and may be characterized and used as a comparative parameter between different groups to evaluate the health status of these animals.

Key words: Hematology; Reptiles; Chelonoidis carbonarius; Chelonoidis denticulatus

\section{INTRODUCTION}

Hematological analysis of wild and captivity animals is essential for obtaining details about the nature of the species and represents a simple method that can be used to diagnose disease and predict prognosis (Zago et al., 2010a; Bergamini, 2011).

Diverse hematological studies have been performed in mammals and characterization of their blood cells and respective biological functions are well established. However, few such studies have been performed in reptiles and there have been many discussions in relation to the morphology and variety of cells (Zhang et al., 2011). Thus, new studies that aim to characterize the morphology of blood cells in new reptile species are extremely important for the hematological understanding of these vertebrates.

The Testudinidae family is composed exclusively of land chelonian species, generally known as land tortoises, Chelonoidis denticulatus [= Chelonoidis denticulata (Linnaeus, 1766)] and C. carbonarius [= C. carbonaria (Spix, 1824)] (Olson and David, 2014), which is the only species of this family found in Brazil. Only few studies have described the morphology of chelonian blood cells, which are more common for sea and freshwater turtle species (Pires et al., 2006; Ferronato et al., 2009; Santos et al., 2009; Zago et al., 2010b).

Cytochemical analyses enable the recognition of a variety of blood cells, and represent an accessible, economic, and timely method to characterize distinct cell types and to examine the hematological health of the animals (Stacy et al., 2011). Thus, in order to contribute to the understanding and recognition of different chelonian cells types, the present study aimed to characterize the blood cells of the two species of Brazilian tortoises.

\section{MATERIAL AND METHODS}

Animals were identified based on morphological characteristics as described by Williams (1960), Castanõ-Mora and Lugo-Rugeles (1981), and Pritchard and Trebbau (1984). The animals were labeled on the carapace by using plastic tags and photographed (Figure 1). 

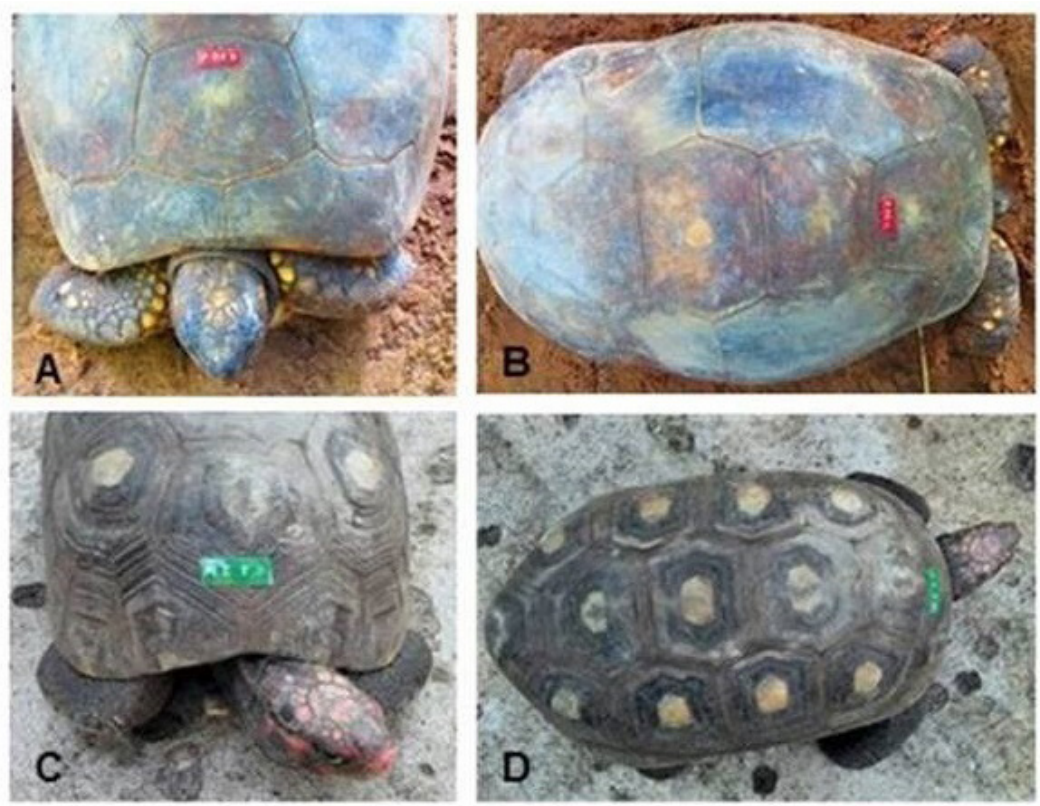

Figure 1. Brazilian specimens of the Testudinidae family. A. B. Chelonoidis denticulatus; C. D. Chelonoidis carbonarius. Source: pictures obtained by the author at Bosque Municipal de São José do Rio Preto, SP, and Zoológico Municipal Missina Palmeira Zancaner of Catanduva, SP.

Peripheral blood was sampled from the marginal costal vein of 20 animals from Bosque Municipal of São José do Rio Preto, SP, Brazil, from Jacarezário of Unesp Rio Claro, SP, Brazil and from Zoológico Municipal Missina Palmeira Zancaner of Catanduva, SP, Brazil, 10 specimens each of $C$. denticulatus and $C$. carbonarius; five animals each of the specimens were males and females.

Blood was sampled from animals in captivity according to the method described by Silva et al. (2012). After cleaning the sampling site with distilled water and $70 \%$ ethanol, the marginal costal vein was punctured and approximately $1 \mathrm{~mL}$ blood was collected and deposited in a tube containing the anticoagulant sodium heparin. Samples were then refrigerated until use within $24 \mathrm{~h}$ to prevent sample degradation.

After sampling, blood smears were performed in duplicate for each animal and the slides were stained with Panótico ${ }^{\circledR}$ (Zago et al., 2010b). The blood smears were viewed under an Olympus BX-60 light microscope coupled to a digital camera and image analysis system, under 1000X magnification. All procedures were approved by Comissão de Ética em Experimentação Animal (CEEA) of Universidade Estadual Paulista "Júlio de Mesquita Filho", São José do Rio Preto (No. 018/09) and IBAMA/SISBIO (No. 19514-1).

\section{RESULTS AND DISCUSSION}

Following the cytochemical analysis of tortoise blood tissue, it was possible to describe all of the chelonian cell types (Figure 2), with the exception of thrombocytes, probably because the blood tubes contained the anticoagulant sodium heparin. 

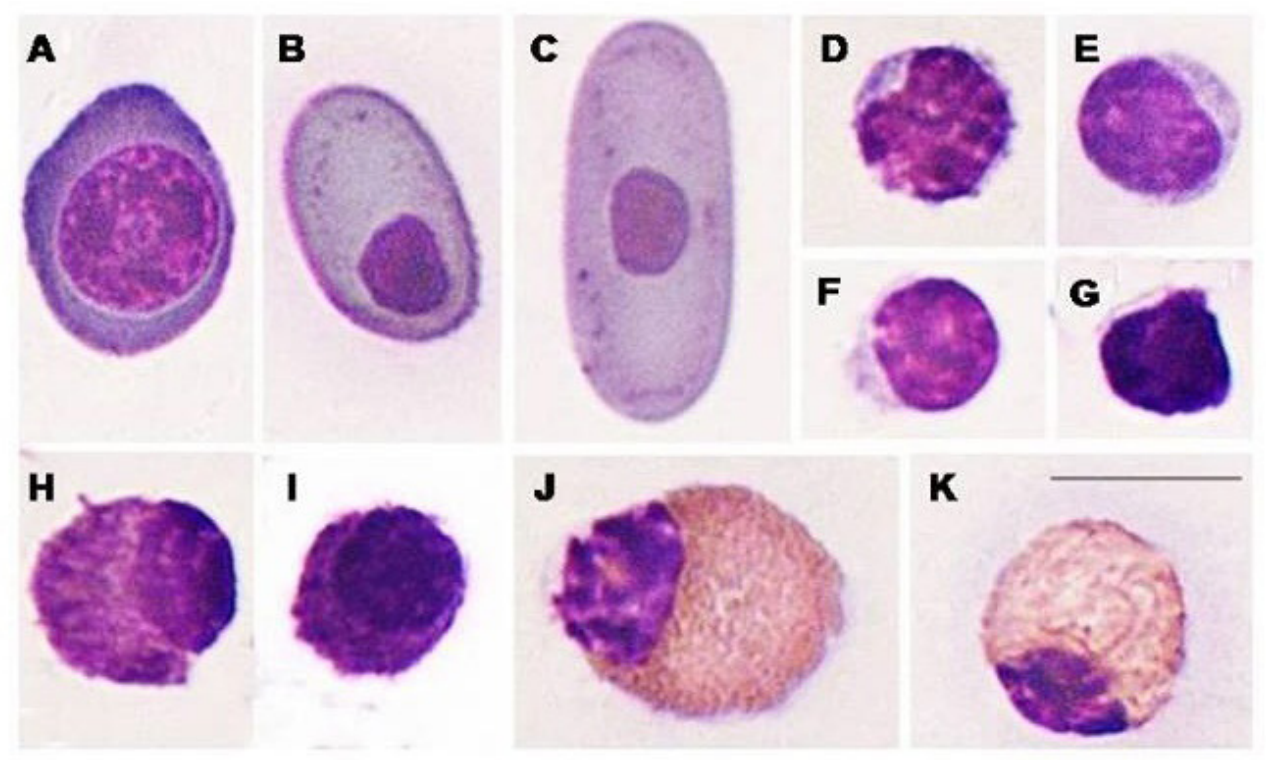

Figure 2. Blood cells of Chelonoidis carbonarius and Chelonoidis denticulatus stained with Panótico ${ }^{\circledR}$. A. B. Polychromatophils at different stages of maturity; C. Mature Erythrocyte; D. Monocyte; E. F. Lymphocytes; G. Azurophils; H. Eosinophils; I. Basophils; J. K. Heterophils. Bar $=10 \mu \mathrm{m}$.

Testudine cell types may be categorized as erythrocytes, leukocytes, and thrombocytes. Leukocytes are subdivided into agranulocytes (monocytes and lymphocytes) and granulocytes (eosinophils, heterophils, basophils, and azurophils) (Zhang et al., 2011).

\section{Erythrocytes}

The immature form of erythrocytes, called polychromatophils, was observed (Figure 2A and $\mathrm{B}$ ) as well as the mature form (Figure $2 \mathrm{C}$ ). Polychromatophils were observed at different stages of maturity (Figure 2A and B). These cells are more rounded and basophilic, with a larger nucleus (round, oval, or irregular) and higher nucleus/cytoplasm ratio when compared to mature erythrocytes, as described for reptiles (Stacy et al., 2011). It is common to find a small percentage of immature erythrocytes in reptile blood. These cells are relatively small compared with mammalian polychromatophils, and they gradually increase in size during maturation (Stacy et al., 2011).

Mature erythrocytes in tortoises are nucleated with an elliptical shape, and with the nucleus positioned in the center of the cell, showing basophilic condensed chromatin, as previously described for turtles (Zhang et al., 2011). Erythrocytes exhibit a purple nucleus and large pale purple cytoplasm when stained with Panótico ${ }^{\circledR}$ (Figure 2C).

Although they are morphologically different from mammalian erythrocytes, owing to the presence of a nucleus, these blood cells carry out the same basic function of gas exchange (Goulart, 2004). The life-time of mature erythrocytes of reptiles, in general, ranges from 600 to 800 days showing that the rate of renewal of this cell type is much slower than that of human erythrocytes, which live for about 120 days (Stacy et al., 2011). This may be associated with the slower metabolism of reptiles and the fact that these cells are nucleated in these animals (Stacy et al., 2011). 


\section{Agranular leukocytes}

\section{Monocytes}

Monocytes (Figure 2D), as described for reptiles (Stacy et al., 2011), presented a round or oval shape, a nucleus with a reniform or rod shape, which covers the larger portion of the cell area (little cytoplasm). Furthermore, Stacy et al. (2011) noted that reptilian monocytes are of varied size $(8-25 \mu \mathrm{m})$ and are similar to mammalian monocytes. The nucleus showed a purple color and lilac or pale blue cytoplasm when stained with Panótico ${ }^{\circledR}$ (Figure 2D).

This cell type is found at low levels in turtles and reptiles, accounting for $0-10 \%$ of all leukocytes, and reaches $20 \%$ in some species (Goulart, 2004). The high rates of monocytes in the peripheral circulation are related to chronic inflammation and bacterial and parasitic infections. Therefore, for an effective immune response against tissue invasion, these cells need to differentiate into macrophages (Stacy et al., 2011).

\section{Lymphocytes}

Lymphocytes (Figure 2E and F) were viewed as rounded cells and contained rounded nuclei and little cytoplasm, as described by Zhang et al. (2011) for turtles.

Reptile lymphocytes are 5-11 $\mu \mathrm{m}$ in size (Zhang et al., 2011) and can be easily confused with thrombocytes or monocytes, but are differentiated by the presence of little cytoplasm and a rounded nucleus, with the thrombocytes being elliptical or oval in shape, and monocytes having a kidney-shaped nucleus (Stacy et al., 2011). Lymphocytes exhibit purple nucleus and lilac or light blue cytoplasm, when stained with Panótico ${ }^{\circledR}$ (Figure 2E and F).

The numbers of this cell type in reptile blood are variable and may be related to many factors such as seasonality, sex, nutrition, and reproductive period. Thus, lymphocytes may fluctuate within a range of $15-90 \%$ of the total leukocytes (Goulart, 2004).

In the same way as lymphocytes from birds and mammals, reptile lymphocytes can be classified as $B$ and $T$ cells, which are responsible for producing immunoglobulins and eliciting immune responses, respectively (Stacy et al., 2011). An increase in the proportion of this cell type in the blood is known as lymphocytosis and may indicate inflammation, scarring, parasitic infections, or viral infection; moreover, a decrease in the number of lymphocytes, known as lymphopenia, may be associated with malnutrition (Stacy et al., 2011).

\section{Granular leukocytes}

\section{Azurophils}

Azurophils were observed in blood smears from tortoises (Figure 2G). These cells are characterized by an irregular shape, a nucleus with peripheral heterochromatin, and cytoplasm with few organelles (Zago et al., 2010b). They have a dark purple nucleus and inconspicuous cytoplasm when stained with Panótico ${ }^{\circledR}$ (Figure $2 \mathrm{G}$ ).

According to Stacy et al. (2011), azurophils are unique to reptiles, being similar in size and shape to lymphocytes, and can be differentiated by their irregular shape and more intense nucleus color when stained with Panótico ${ }^{\oplus}$. These cells are commonly found in lizard and crocodile 
blood, and less frequently in turtles. A change in the number of azurophils may represent cases of inflammation or infectious disease (Stacy et al., 2011).

\section{Eosinophils}

Eosinophils (Figure $2 \mathrm{H}$ ) were characterized by cell size, the peripheral position of the nucleus, and large cytoplasm filled with rounded granules. Moreover, when stained with Panótico ${ }^{\circledR}$, eosinophils had a dark purple nucleus situated at the margin of cells, and cytoplasm filled with lighter purple colored granules (Figure $2 \mathrm{H}$ ).

Stacy et al. (2011) emphasized that reptile eosinophils are sized between 9 and $20 \mu \mathrm{m}$ and are similar to heterophils in size and shape, with which they are easily confused. These cells can be differentiated mainly by the shape of the cytoplasmic granules, because heterophils have elongated orange granules and eosinophils exhibit rounded purple granules (Zago et al., 2010b; Stacy et al., 2011).

In healthy reptiles, eosinophils usually represent $7-20 \%$ of the total leukocytes, being less frequent in lizards and more common in turtles (Stacy et al., 2011). An increase in the proportion of this cell type may be associated with parasitic infection (Goulart, 2004).

\section{Basophils}

The analysis of the basophils demonstrated that these cells are rounded and may be characterized by the presence of numerous cytoplasmic granules (Figure 2l). Besides these features, it can be noted that reptile basophils are generally sized between 9.5 and $16 \mu \mathrm{m}$, and the granules often obscure visualization of the nucleus (Zhang et al., 2011). When stained with Panótico ${ }^{\circledR}$, basophils have dark purple nuclei and rounded purple granules distributed throughout the cytoplasm (Figure 2I).

The percentage of basophils is variable among reptile species, so that some species of turtles and tortoises may have $0-40 \%$ of all leukocytes, but some species of fresh-water turtles may present more than $65 \%$ (Stacy et al., 2011). These authors note that the high levels of basophils in turtles seem to have no association with external factors, but for other reptiles, an increased number of basophils in the blood can be associated with blood parasites and viral infections (Bergamini, 2011; Stacy et al., 2011).

\section{Heterophils}

Heterophils presented a purple peripheral nucleus and cytoplasm full of elongated and fusiform orange granules (Figure $2 \mathrm{~J}$ and $\mathrm{K}$ ). These cells are unique to birds and reptiles and are sized between 12 and $23.8 \mu \mathrm{m}$, being larger than other cell types, which can facilitate their classification even though they are often confused with eosinophils (Bergamini, 2011; Zhang et al., 2011). However, we emphasize that when stained with Panótico ${ }^{\circledR}$, heterophils can be easily differentiated from other cell types by the orange color of their cytoplasm.

In reptiles, the percentage of heterophils can range between 30 and $45 \%$ of all leukocytes, but some species of turtles and crocodiles can present more than $50 \%$ of this cell type (Stacy et al., 2011). The high percentages of heterophils can indicate bacterial infections (Goulart, 2004).

These data are of high importance for establishing hematological profiles of Brazilian 
tortoises and of reptiles. Therefore, based on our results and on a comparative analysis of data from the literature for other species of reptiles, we can conclude that the blood cells described for Brazilian tortoises are found in all species of reptiles that have been analyzed and characterized thus far, and can be used as a comparative parameter between different groups to evaluate the health status of these animals.

In conclusion, by analyzing blood samples of $C$. carbonarius and $C$. denticulatus, it was possible to characterize and describe all cell types of Brazilian Testudinidae. Thus, the comparison of our results with data in the literature allows us to conclude that the cells of Brazilian Testudinidae are morphologically and physiologically similar to the cells of other reptiles.

\section{ACKNOWLEDGMENTS}

We thank Bosque Municipal of São José do Rio Preto, SP, Jacarezário of Unesp, Rio Claro, Zoológico Municipal Missina Palmeira Zancaner of Catanduva, SP, for giving the tortoise specimens, and development agencies: CNPq (Notice Universal N 475074/2012-2) and Programa Institucional de Bolsas de Iniciação Científica of UNESP (PIBIC) for financial support.

\section{REFERENCES}

Bergamini BCS (2011). Valores hematológicos em Geochelone carbonaria (Jabuti). Monograph, FMVZ/UNESP, Botucatu.

Castanõ-Mora OV and Lugo-Rugeles M (1981). Estudio comparativo del comportamiento de los especies de morrocoy: Geochelone carbonaria y Geochelone denticulata y aspectos comparables de su morfología externa. Cespedesia 10: 55-122.

Ferronato BO, Genoy-Puerto A, Pinã Cl, Souza FL, et al. (2009). Notes on the hematology of free-living Phrynops geoffroanus (Testudines: Chelidae) in polluted rivers of Southeastern Brazil. Zoologia 26: 795-798. http://dx.doi.org/10.1590/S1984$\underline{46702009000400027}$

Goulart CES (2004). Hematologia Aplicada. In: Herpetologia, Herpetocultura e Medicina de Répteis. Editora L. F. Livros e Veterinária Ltda, Rio de Janeiro, 131-144.

Olson SL and David N (2014). The gender of the tortoise genus Chelonoidis Fitzinger, 1835 (Testudines: Testudinidae). Proc. Biol. Soc. Wash. 126: 393-394. http://dx.doi.org/10.2988/0006-324X-126.4.393

Pires TT, Rostan G and Guimarães JE (2006). Hemograma e determinação da proteína plasmática total de tartarugas marinhas da espécie Carettacaretta (Linnaeus, 1758), criadas em cativeiro, Praia do Forte, Município de Mata de São João-Bahia. Braz. J. Vet. Res. Anim. Sci. 43: 348-353.

Pritchard PCH and Trebbau P (1984). The Turtles of Venezuela. SSAR Contrib Herpetol. Ithaca 2: 11-117.

Santos MRD, Ferreira LS, Batistote C, Grossman A, et al. (2009). Valores hematológicos de tartarugas marinhas Cheloniamydas (Linaeus, 1758) juvenis selvagens do Arquipélago de Fernando de Noronha, Pernambuco, Brasil. Braz. J. Vet. Res. Anim. Sci. 46: 491-499.

Silva TL, Silva MIA, Venancio LPR, Zago CES, et al. (2012). Blood sampling in Testudinidae and Chelidae. Herpetol. Rev. 43: 64-65.

Stacy NI, Alleman AR and Sayler KA (2011). Diagnostic hematology of reptiles. Clin. Lab. Med. 31: 87-108. http://dx.doi. org/10.1016/j.cll.2010.10.006

Williams EE (1960). Two Species of Tortoises in Northern South America. Breviora. Museum of Comparative Zoology, Cambridge, Mass.

Zago CES, Ferrarezi AL, Vizotto LD, Oliveira C, et al. (2010a). Hemoglobin polymorphism and hematological profile of Geoffroy's side-necked turtle (Phrynops geoffroanus, Testudines) in the northwestern region of São Paulo State, Brazil. Genet. Mol. Res. 9: 721-726. http://dx.doi.org/10.4238/vol9-2gmr731

Zago CES, da Silva TL, da Silva MIA, Venancio LPR, et al. (2010b). Morphological, morphometrical and ultrastructural characterization of Phrynops geoffroanus' (Testudines: Chelidae) blood cells, in different environments. Micron 41: 10051010. http://dx.doi.org/10.1016/j.micron.2010.06.006

Zhang F, Gu H and Li P (2011). A Review of Chelonian Hematology. Asian Herpetol. Res. 2: 12-20. http://dx.doi.org/10.3724/ SP.J.1245.2011.00012 